\title{
CARACTERIZAÇÃO GPR DE TAMBORES METÁLICOS E PLÁSTICOS ESTUDO SOBRE $O$ SÍTIO CONTROLADO DO IAG/USP
}

\author{
Selma Isabel Rodrigues \\ Orientador: Dr. Jorge Luís Porsani (IAG-USP) \\ 89 p - Dissertação (Mestrado) - Defesa 24.08.2004
}

\begin{abstract}
RESUMO. Nesta pesquisa, o método geofísico GPR - Ground Penetrating Radar foi utilizado para caracterizar tambores metálicos e plásticos enterrados numa área de testes controlados, denominada de "Sítio Controlado de Geofísica Rasa - SCGR do IAG" instalado no campus da Universidade de São Paulo, em São Paulo. Os alvos foram escolhidos visando simular estudos de contaminação ambiental e obras de engenharia dentro do contexto urbano. Os tambores metálicos (vazios) foram dispostos na vertical e horizontal e os tambores plásticos (vazios, preenchidos com água salgada e com água fresca) foram dispostos na vertical. Foram realizadas simulações numéricas GPR 2D para auxiliar na escolha dos parâmetros ótimos referentes à aquisição dos dados e verificar se os contrastes existentes entre os alvos (tambores metálicos e plásticos) e 0 background poderiam produzir reflexões significativas. As aquisições foram realizadas "antes" e "depois" da instalação dos alvos no SCGR-IAG utilizando as antenas de $100 \mathrm{MHz}, 200 \mathrm{MHz}$ e $500 \mathrm{MHz}$. Após as aquisições, os dados GPR foram processados e em seguida analisados visando estabelecer respostas típicas para cada alvo, considerando o tipo de material, a sua composição e/ou preenchimento. Os resultados foram comparados com as informações das profundidades reais dos alvos enterrados e as simulações numéricas, os quais apresentam uma excelente concordância. Além disso, permitiram identificar com clareza todos os alvos e diferenciá-los quanto ao padrão de reflexão. Nos tambores plásticos foi possível distinguir os que estavam vazios e os preenchidos com água fresca ou com água salgada. Essas respostas obtidas em uma área de testes controlados podem ser consideradas como típicas para os alvos, podendo ser extrapoladas para áreas onde não se tem nenhuma informação da subsuperfície.
\end{abstract}

ABSTRACT. In this research, geophysical method GPR - Ground Penetrating Radar was used to characterize metallic and plastic drums buried in an area of controlled tests, called "Controlled Site of Shallow Geophysics" (SCGR-IAG - Sitio Controlado de Geofísica Rasa) installed in the campus of the University of São Paulo, in São Paulo. The targets were chosen aiming to simulate studies of environmental contamination and works of engineering inside the urban context. The metallic drums (empty) were disposed in the vertical and the horizontal position, and the plastic tubes (empty, filled with salty water and cool water) were disposed in the vertical position. 2D GPR numerical simulations were carried through to assist in the choice of the excellent parameters referring to the acquisition of the data, and to verify if the contrasts between the targets (metallic and plastic tubes) and the background could produce significant reflections. The acquisitions were carried through "before" and "after" the installation of the targets at the SCGR-IAG using $100 \mathrm{MHz}, 200 \mathrm{MHz}$ and $500 \mathrm{MHz}$ antennas. After the acquisitions, GPR data were processed and then analyzed to establish typical answers to each target, considering the type of material, its composition and/or fulfilling. The results were compared with the information of the real depths of the buried targets and the numerical simulations, which matched in an excellent agreement. Moreover, the results allowed to identify with clarity all the targets and differentiate them according to the reflection standard. In the plastic drums it was possible to distinguish the ones that were empty and the filled ones with cool water or salty water. These answers gotten in an area of controlled tests can be considered as typical for the targets, being able to be surpassed for areas where no information of the subsurface is had. 